\title{
LANDFILL SITE SELECTION USING GIS TECHNOLOGY AND THE ANALYTIC HIERARCHY PROCESS
}

\author{
Dragoljub J. Sekulovića , Gordana L. Jakovljevićb \\ a University of Defense in Belgrade, Military Academy, \\ Belgrade, Republic of Serbia, \\ e-mail: sekulovicdr@yahoo.co.uk, \\ ORCID iD: Dhttp://orcid.org/0000-0003-1617-1296 \\ ${ }^{\mathrm{b}}$ University of Banja Luka, Faculty of Architecture, Civil Engineering \\ and Geodesy, Banja Luka, Republic of Srpska, \\ Bosnia and Herzegovina, \\ e-mail: gordana.jakovljevic@agfbl.org, \\ ORCID iD: (1)http://orcid.org/0000-0003-2784-8370
}

DOI: 10.5937/vojtehg64-9578

FIELD: Earth Sciences

ARTICLE TYPE: Original Scientific Paper

ARTICLE LANGUAGE: English

\section{Abstract:}

Landfills are one of the most common ways of waste disposal. Selecting a landfill site is a complicated and long process that involves a legal framework as well as environmental, economic and social parameters aimed at reducing a negative environmental impact. The landfill site selection in the municipality of Nevesinje (Republic of Srpska), dealt with in this paper, was performed using the analytic hierarchy process $(A H P)$ and GIS technology. Eight criteria were analyzed: geology, distance from settlements, distance from road networks, distance from water bodies, vegetation, slope, elevation and aspect. Relative weighting factors for each criterion were defined by applying the AHP and their linear combinations, with the range of each cell determined by the suitability index. The suitability index has been reclassified in five classes where $67 \%$ of the territory belongs to the restricted area, $11 \%$ of the territory has low suitability, $6.1 \%$ has moderate suitability, $5.9 \%$ high suitability, and $10 \%$ very high suitability. Two potential landfill sites are proposed, but before a final decision is made, it is necessary to analyze additional parameters.

Key words: landfill, site selection, AHP, GIS. 


\section{Introduction}

A lack of land for waste disposal, inadequate landfill sites and rapid population growth are some of the biggest problems of urban areas in the world. Landfills are an important element in the waste disposal management system. According to the Law on Waste Management of the Republic of Srpska (RS), a landfill is a site for waste disposal on the surface or below the surface where waste is disposed of, and that includes: internal storage areas, and a permanent site (over a year) which is used for temporary storage of waste (Official Gazette of the Republic of Srpska, 28/1994). The landfill site selection includes social and economic parameters, environment and legislation (Zamorano, et al, 2008, pp.473-481). An inadequate site selection causes: transfer of disease, pollution of water, soil and atmosphere, disruption of landscape value, unpleasant smell and economic losses. A site selection is a multi-criterion process which considers different criteria for the selection of suitable areas between different alternatives (Melo, et al, 2006, pp.83-92), (Nazari, et al, 2012, pp.1631-1642). The integration of GIS technology and the multi-criteria analysis is a powerful tool for the selection of a landfill site, because GIS enables an efficient manipulation and presentation of spatial data and the MCDA (multi-criteria decision analysis) consistently ranks potential sites based on different criteria (Kontos, et al, 2005, pp.818-832) and (Sener, et al, 2006, pp.376-388). Researchers use different MCDA methods for a landfill site selection. Siddiqui, et. al. (1996, pp.515-523) applied the combination of GIS and the Analytic Hierarchy Process (AHP). In (Chang, et al, 2008, pp.139-153) GIS and the fuzzy MCDA are integrated for a choice of locations in suburban areas, Tayyeb, et.al. (2010, pp.1073-1078) uses the MCDA and the analytic network process (ANP). Sener, et. al. (2006, pp.376388) uses a combination of the AHP and linear combinations of weight, whereas (Akbari, 2008, pp.39-47) applied a combination of GIS, the Fuzzy multi-criteria analysis and the System Supporting Spatial Decision-making (SDSS). Mahini and Gholamalifard (2006, pp.435-445) described the multicriteria analysis, called a linear combination of weight in the GIS environment.

In the site selection, it is very important to consider natural, social, political, economic and technical factors; therefore, a choice must be made by a multidisciplinary team of experts.

\section{Methodology}

\section{Study area}

Nevesinje is located in the southeastern part of the Republic of Serbian $(\mathrm{BiH})$, east of Mostar and south of Sarajevo. It is located

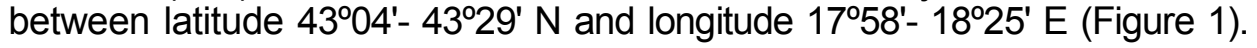


The Mulicipality is a mountainous region of High-Herzegovina with an average altitude of $860 \mathrm{~m}$, and is characterized by a large karst field of 17,000 ha. The area of the Municipality of Nevesinje is $923.4 \mathrm{~km}^{2}$. The Municipality Nevesinje has a population of 13,713 inhabitants (http://www.opstinanevesinje.rs.ba/,nd).

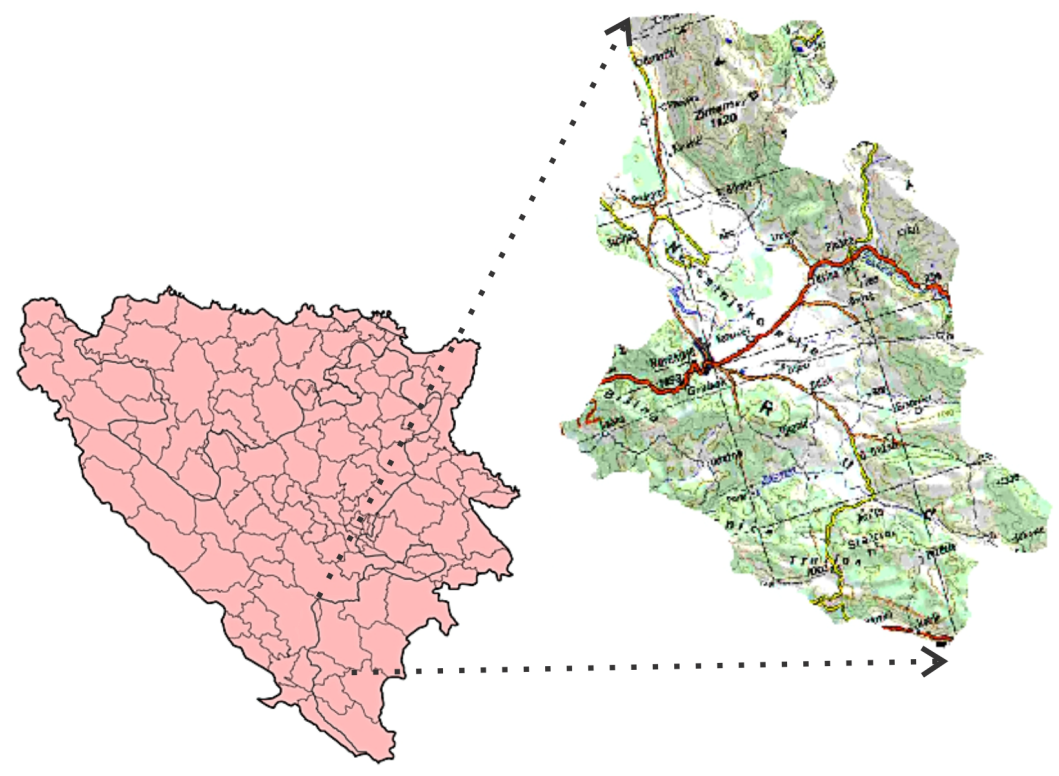

Figure 1 - Geographical location of the Municipality of Nevesinje in RS

Puc. 1 - Географическое положение Муниципалитета Невесинье, Республика Сербская Slika 1 - Geografski položaj opštine Nevesinje, Republika Srpska

Method

A landfill site selection was carried out by a combination of GIS technology and the Analytic Hierarchy Process - AHP. GIS technology combines spatial data (maps, photogrammetric imagery, topography and satellite imagery) with quantitative, qualitative and descriptive databases and it supports a wide range of spatial analyses. In the decision making process, a large number of factors must be considered, and GIS is ideal for such studies because it allows easy manipulation of large amounts of spatial data from different sources. The AHP is a technique that, integrated into GIS, allows a consistent estimate, based on the factors that contribute to the analysis of problems. A schematic presentation is shown in Figure 2. 


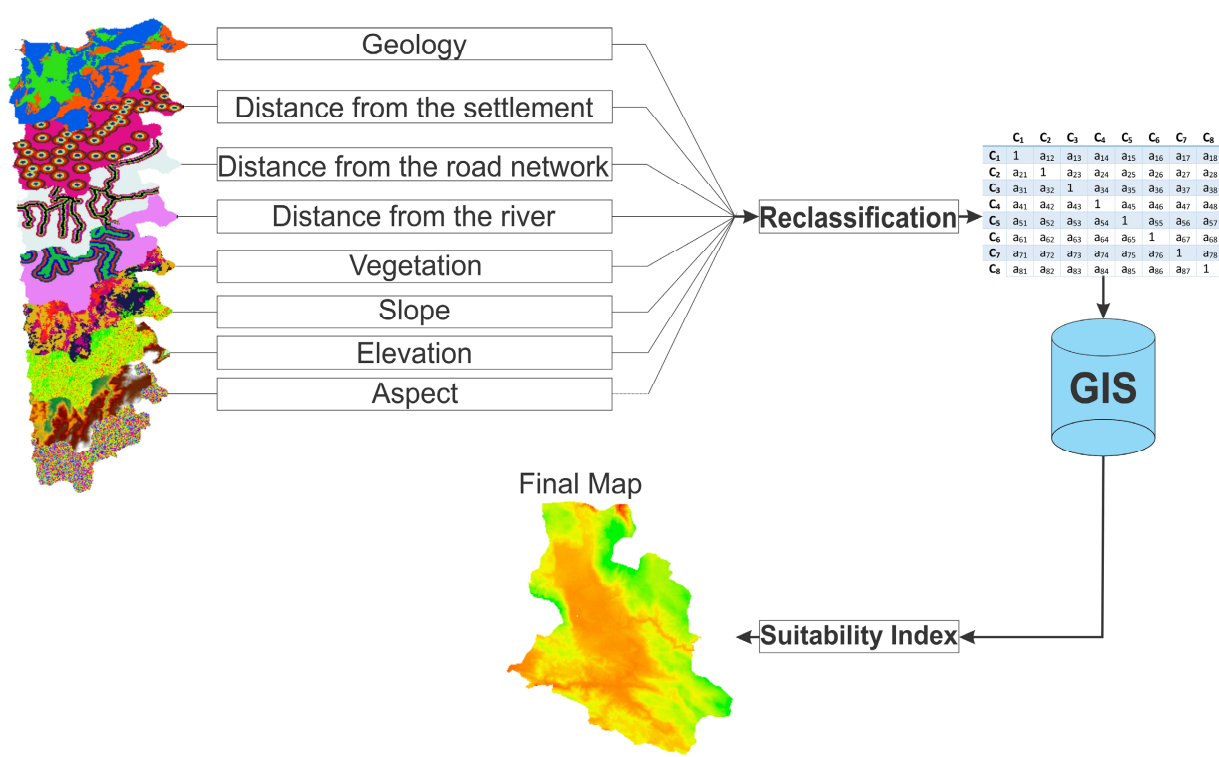

Figure 2 - Scheme of a landfill site selection using GIS and the AHP Puc. 2 - Схема процесса выбора местности для обустройства свалки по ГИС технологии и методам АНP

Slika 2 - Šematski prikaz procesa izbora lokacije za deponiju primenom GIS tehnologije i AHP

The AHP is a powerful tool for consistent evaluation and entails four steps (Saaty, 2008, pp.83-98). The first step defines a problem. The second one is based on a representation of the problem in the hierarchical structure. The hierarchy structure consists of several levels: goal, criteria, sub-criteria and alternatives. The definition of the hierarchy structure for a landfill site selection includes environmental, economic and legal factors. In the third step, a matrix of comparison is generated as a result of a pairwise comparison of the elements of the hierarchy in the top-down sistem. The AHP provides a possibility to find relations between significant factors, establishes priorities with their relative importance in real conditions and determines the predominance of one factor. The goal is at the top of the hierarchy and it is not comparable. At the first level, $n$ criteria were compared in pairs and with respect to a pattern element at a higher level. If an element $A$ is $n$ times preferred over $B$, then $B$ is preferred $1 / n$ over $A$. The comparison of two elements of the hierarchy, at the same level, is performed using Saaty's fundamental scale with 9 levels of relative importance - Table 1 (Saaty, 2008, pp.83-98). 
Table 1 - Saaty's fundamental scale Таблица 1 - Фундаментальная шкала Саати Tabela 1 - Sartijeva fundamentalna skala

\begin{tabular}{|c|c|}
\hline Importace & Definition \\
\hline 1 & Equal importance \\
\hline 3 & Weak dominance \\
\hline 5 & Strong dominance \\
\hline 7 & $\begin{array}{c}\text { Demonstrated } \\
\text { dominance }\end{array}$ \\
\hline 9 & Absolut dominance \\
\hline $2,4,6,8$ & Intermediate values \\
\hline
\end{tabular}

The results of the comparisons of elements at a given level of the hierarchy are placed in the appropriate matrix $A$.

$$
A=\left[\begin{array}{ccc}
a_{11} & \cdots & a_{1 n} \\
\vdots & \ddots & \vdots \\
a_{n 1} & \cdots & a_{n n}
\end{array}\right]
$$

The fourth step uses the comparison matrix to weigh priorities. In a completely consistent evaluation, the pairwise comparison matrix $A$, containing the comparison results, would be identical to the matrix $\mathrm{X}$ :

$$
\mathrm{X}=\left[\begin{array}{ccc}
\frac{\mathrm{w}_{1}}{\mathrm{w}_{1}} & \cdots & \frac{\mathrm{w}_{1}}{\mathrm{w}_{\mathrm{n}}} \\
\vdots & \ddots & \vdots \\
\frac{\mathrm{w}_{\mathrm{n}}}{\mathrm{w}_{1}} & \cdots & \frac{\mathrm{w}_{\mathrm{n}}}{\mathrm{w}_{\mathrm{n}}}
\end{array}\right]
$$

where $\mathrm{w}_{\mathrm{i}}$ denotes the relative weighted coefficient of the element $i$. The weight vector $\mathrm{w}_{\mathrm{i}}$ can be calculated by solving the following system of homogenous linear equations: $\mathrm{A} \cdot \mathrm{W}=\mathrm{n} \cdot \mathrm{W}$ or $(\mathrm{A}-\mathrm{n} \cdot \mathrm{I}) \cdot \mathrm{w}=0$ where $n$ is the eigenvalue of the comparison matrix $A$.

The AHP allows the user to identify and analyze the consistency of decision-makers in the process of discernment and evaluation of the hierarchy elements. Also, it is possible to determine errors of judgment by calculating the consistency index $(\mathrm{Cl})$ for the comparison matrix, and then calculating the consistency ratio (CR).

$$
\mathrm{CR}=\frac{\mathrm{CI}}{\mathrm{RI}}
$$


where $R I$ is the random consistency index and it depends on the order of the matrix $A$.

$$
\mathrm{CI}=\frac{\lambda_{\max }-\mathrm{n}}{\mathrm{n}-1} .
$$

where $\lambda_{\max }$ is the largest eigenvalue of the comparison matrix. The closer the value of the computed $\lambda$ max is to $n$, the more consistent the observed values are. If the consistency ratio is $C R \leq 0.1$, all results should be analyzed again (Inđić, et al, 2014, pp.23-41).

Finally, the sensitivity index is calculated using the linear combination of weight (WLC method), by multiplying the rank of each alternative with the weight factor:

$$
\mathrm{S}_{\mathrm{i}}=\sum_{\mathrm{i}=1}^{\mathrm{n}} \mathrm{w}_{\mathrm{i}} \cdot \mathrm{r}_{\mathrm{j}}
$$

Where $S_{i}$ is the suitability index for a landfill site selection, $w_{i}-$ the weight coefficient $i, r_{i}$ - the rang $j$ cells of the raster within the criteria $i$. Using equation (2) model expAhp 2.0. (http://www.arcgis.com/home/item.html?id=bb3521d...,nd) automatically calculates the sensitivity index $\mathrm{S}_{\mathrm{i}}$. A higher suitability index points to a higher possibility that a raster cell becomes a part of the landfill.

\section{Criteria}

After defining the goal, based on legislation and recommendations from literature, 5 limitations and 8 criteria (Table 3) were defined: geology, distance from settlements, distance from road networks, distance from surface streams, vegetation, slope, altitude and aspect (Zamorano, et al, 2008, pp.473-481), (Kontos, et al, 2005, pp.818-832), (Nazari, et al, 2012, pp.1631-1642), (Akbari, 2008, pp.39-47), (Gorsevski, et al, 2012, pp.287-296), (Zelenović, et al, 2011).

\section{Geology}

A landfill should be located in areas with a low risk of groundwater contamination. The contamination of groundwater primarily depends on the permeability and the depth of the strata beneath the landfill (Gorsevski, et al, 2012, pp.287-296). High permeability of the strata occurs in karst formations (such as limestone) and sandy soil, low permeability is characteristic for clayey soils, while the clay shales are impermeable (Kontos, et al, 2003, pp.267-277). 


\section{Distance from settlements}

Landfills should not be built near urban or rural areas because of a negative impact on people's health, odor and noise. Studies have shown that with increasing the distance from inhabitated zones, the opposition of the population to landfill construction decreases (Akbari, 2008, pp.39-47). The EU Directive defines the minimum distance from residential areas which is $500 \mathrm{~m}$ (Official Journal of the European Union, Directive 2008/98 / EC).

\section{Distance from road networks}

An access to a landfill should be provided through alternative roads in all weather conditions (Sener, et al, 2010, pp.2037-46). On the other hand, landfills should be located near existing road networks because a construction of new roads leads to additional costs (Nas, et al, 2010, pp.491-500). Closer distances to the existing roads have higher weight.

\section{Distance from water bodies}

The Water Law of the Republic of Srpska prohibits the construction of landfills near water bodies (springs, rivers, lakes, wetlands) (Official Gazette of the Republic of Srpska, 50/2006 and 92/2009), (Nas, et al, 2010, pp.491-500). The EU Directive defines the minimum distance from permanent water streams and water sources, which is 500 meters (Official Journal of the European Union, Directive 2008/98/EC).

\section{Vegetation}

The Forests Law of the Republic of Srpska, prohibits waste disposal in forests and forest lands (Official Gazette of the Republic of Srpska, $66 / 2003,75 / 2008$ and 30/2010). Pastures, irrigated and non irrigated fertile areas are not suitable land for landfills.

\section{Slope and elevation}

Slope and elevation are the basic parameters for landfill construction (Kontos, et al, 2005, pp.818-832). Areas with high altitudes and slopes are not suitable for landfill sites. The best locations for landfills are areas of a medium altitude, surrounded by hills and with a slope less than $20 \%$ (Gorsevski, et al, 2012, pp.287-296). The slope affects the amount of water in the soil, the possibility of erosion rate, surface runoff and groundwater. The slope is crucial for the construction of landfill sites, because a higher slope causes higher costs of construction. 


\section{Aspect}

The effect of wind must be taken into account because odors arising from landfills should not be felt in urban areas. Aspect oriented to the direction of prevailing winds is not suitable for a landfill site. By analyzing the strength and frequency of wind in the municipality of Nevesinje, it was found that the dominant direction of wind is north $(\mathrm{N})$ and south $(\mathrm{S})$, and the areas with this aspect have the lowest suitability.

\section{Date collection and processing}

After defining the goal, limitations and criteria, it is necessary to collect and enter data into GIS. In GIS, each of the limitations and criteria is presented in the form of a spatially defined vector or a raster map, the cells of which represent different alternatives. All GIS processes (digitalization, conversion, 3D analysis, etc.) during import and building of the spatial database, are accomplished using the tools of ArcGIS 10.2 software of the ESRI company (Nas, et al, 2010, pp.491-500). The sources and the process of generation of GIS data sets are given in Table 2.

Table 2 - Date sources

Таблица 2 - Источники данных

Tabela 2 - Izvori podataka

\begin{tabular}{|c|c|}
\hline Criteria & Source \\
\hline Geology & $\begin{array}{c}\text { Basic geological map of 1: 100,000 (Released by the } \\
\text { Military Geographical Institute, Belgrade) }\end{array}$ \\
\hline Distance from settlements & \multirow{3}{*}{$\begin{array}{l}\text { Topographic map 1:50,000 (Military Geographical } \\
\text { Institute, Belgrade) }\end{array}$} \\
\hline $\begin{array}{l}\text { Distance from road } \\
\text { networks }\end{array}$ & \\
\hline Distance from rivers & \\
\hline Vegetation & $\begin{array}{l}\text { Corina LandCover } 2006100 \text { x } 100 \text { m } \\
\text { (http://www.eea.europa.eu/, nd) }\end{array}$ \\
\hline Slope & \multirow{3}{*}{$\begin{array}{l}\text { Digital terrain model }{ }^{1} \\
\qquad 20 \times 20 \mathrm{~m}\end{array}$} \\
\hline Elevation & \\
\hline Aspect & \\
\hline
\end{tabular}

Creating a distance from settlements, road networks and rivers was carried out using Multi Buffer tools. The slope and aspect have been created using the Slope and Aspect tool.

\footnotetext{
${ }^{1}$ Digital terrain model, resolution $20 \mathrm{~m} \times 20 \mathrm{~m}$, based on: ortho-photos $(2011,2013)$ and a digitized topographic map 1:50,000.
} 


\section{Criteria evaluation}

After entering data into GIS, criteria were standardized and evaluated. In accordance with practice, experts experience and literature, the suitability of criteria, in this study, was determined using linear standardization in a score range from 1 to 5 , where 5 is the highest and 1 is the lowest suitability (a cell) for a landfill site (Table 4). The reclassification (evaluation) of the criteria was carried out using the Reclass software package ArcGIS 10.2 tool (http://www.esri.com/software/arcgis/arcgis-for-desktop, nd).

Table 3 - Criteria and limitations

Таблица 3 - Критерии и удельные значения

Tabela 3 - Kriterijumi i ograničenja

\begin{tabular}{|c|c|c|c|c|c|}
\hline Criteria & $\begin{array}{c}\text { very low } \\
\text { suitability }\end{array}$ & low suitability & $\begin{array}{c}\text { moderate } \\
\text { suitability }\end{array}$ & high suitability & $\begin{array}{c}\text { very high } \\
\text { suitability }\end{array}$ \\
\hline $\mathrm{C}_{1}$ & al, K1,2,2JK & - & Pr+al, ßßab, ßß & & $\begin{array}{c}2 \mathrm{M} 1+2, \\
1 \mathrm{M} 1+2, \\
2 \mathrm{~K} 2 \text { 2+3, } \\
\text { J,K 3J,K }\end{array}$ \\
\hline $\mathrm{C}_{2}$ & $<500$ & $500-1000$ & $1000-1500$ & $1500-2000$ & $2000<$ \\
\hline $\mathrm{C}_{3}$ & $1000<$ & $750-1000$ & $500-750$ & $250-500$ & 250 \\
\hline $\mathrm{C}_{4}$ & $<500$ & $500-1000$ & $1000-1500$ & $1500-2000$ & $2000<$ \\
\hline $\mathrm{C}_{5}{ }^{*}$ & $(311,312,313$, & $(211,242,243)$ & $(222,321,324)$ & $(333)$ & $(332)$ \\
\hline $\mathrm{C}_{6}$ & $20<$ & - & $10-20$ & & $0-10$ \\
\hline $\mathrm{C}_{7}$ & $1925<$ & $1600-1925$ & $1250-1600$ & $900-1250$ & $550-900$ \\
\hline $\mathrm{C}_{8}$ & $\mathrm{~N}$ & $\mathrm{~S}$ & $\mathrm{~W}, \mathrm{SW}$ & $\mathrm{NW}$ & $\mathrm{E}, \mathrm{SE}, \mathrm{NE}, \mathrm{T}$ \\
\hline
\end{tabular}

${ }^{*}$ CORINA 2006 legend

\section{Determination of criteria weights in the AHP}

The matrix $A$ is the result of the pairwise comparison of 8 criteria (ArcGIS-for-desktop). After the formation of the comparison matrix, which was executed in expAt 2.0. (http://www.arcgis.com/home/item.html?id=bb3521d775c94b28b69a10cd 184b7c1f, nd), the weights of criteria (wi) are calculated for each criterion. The comparison matrix and the weights of criteria are given in Table 4. 
Table 4 - Comparison matrix and the weights of criteria Таблица 4 - Сопоставительная матрица и весовой коэффициент Tabela 4 - Matrica poređenja i težine kriterijuma

\begin{tabular}{|l|c|c|c|c|c|c|c|c|c|}
\hline & $\mathbf{C}_{1}$ & $\mathbf{C}_{2}$ & $\mathbf{C}_{3}$ & $\mathbf{C}_{4}$ & $\mathbf{C}_{5}$ & $\mathbf{C}_{6}$ & $\mathbf{C}_{7}$ & $\mathbf{C}_{8}$ & $\mathbf{w}_{\mathbf{i}}$ \\
\hline $\mathbf{C}_{1}$ & 1 & 3 & 4 & $1 / 2$ & 2 & 4 & 8 & 6 & 0.25 \\
\hline $\mathbf{C}_{2}$ & $1 / 3$ & 1 & 2 & $1 / 2$ & 1 & 2 & 3 & 2 & 0.11 \\
\hline $\mathbf{C}_{3}$ & $1 / 4$ & $1 / 2$ & 1 & $1 / 6$ & $1 / 5$ & 1 & 3 & 2 & 0.06 \\
\hline $\mathbf{C}_{4}$ & 2 & 2 & 6 & 1 & 3 & 4 & 6 & 2 & 0.29 \\
\hline $\mathbf{C}_{5}$ & $1 / 2$ & 1 & 5 & $1 / 3$ & 1 & 3 & 4 & 2 & 0.14 \\
\hline $\mathbf{C}_{6}$ & $1 / 4$ & $1 / 2$ & 1 & $1 / 4$ & $1 / 3$ & 1 & $1 / 2$ & 2 & 0.06 \\
\hline $\mathbf{C}_{7}$ & $1 / 8$ & $1 / 3$ & $1 / 3$ & $1 / 6$ & $1 / 4$ & 2 & 1 & $1 / 3$ & 0.04 \\
\hline $\mathbf{C}_{8}$ & $1 / 6$ & $1 / 2$ & $1 / 2$ & $1 / 4$ & $1 / 2$ & $1 / 2$ & 3 & 1 & 0.05 \\
\hline
\end{tabular}

Taking the weights into consideration, it can be concluded that the distance from the surface flows is the most important criterion; on the other hand, the distance from the road network, altitude, slope and aspect have a minimum weight because they do not significantly affect the environment, but since they determine the cost of construction, they are taken into account.

The value of the consistency ratio $C R=0.062$ was determined on the basis of equation (1). The value $\mathrm{CR} \leq 0.1$ points to the overall consistency of the comparison matrix.

The generation of a landfill suitability map based on the eight criteria was accomplished in the GIS environment. The final realization used the Weighted Linear Combination (WLC) that is integrated into ArcGIS 10.2. (http://www.esri.com/software/arcgis/arcgis-for-desktop), in accordance with equation (2). As a result of multiplying weighted criteria obtained as a result of the AHP, with a cell score of each criterion, the final forest fire risk map is generated. The suitability index is classified into five classes: restricted area, low, moderate, high and very high suitability (Figure 3 ). 


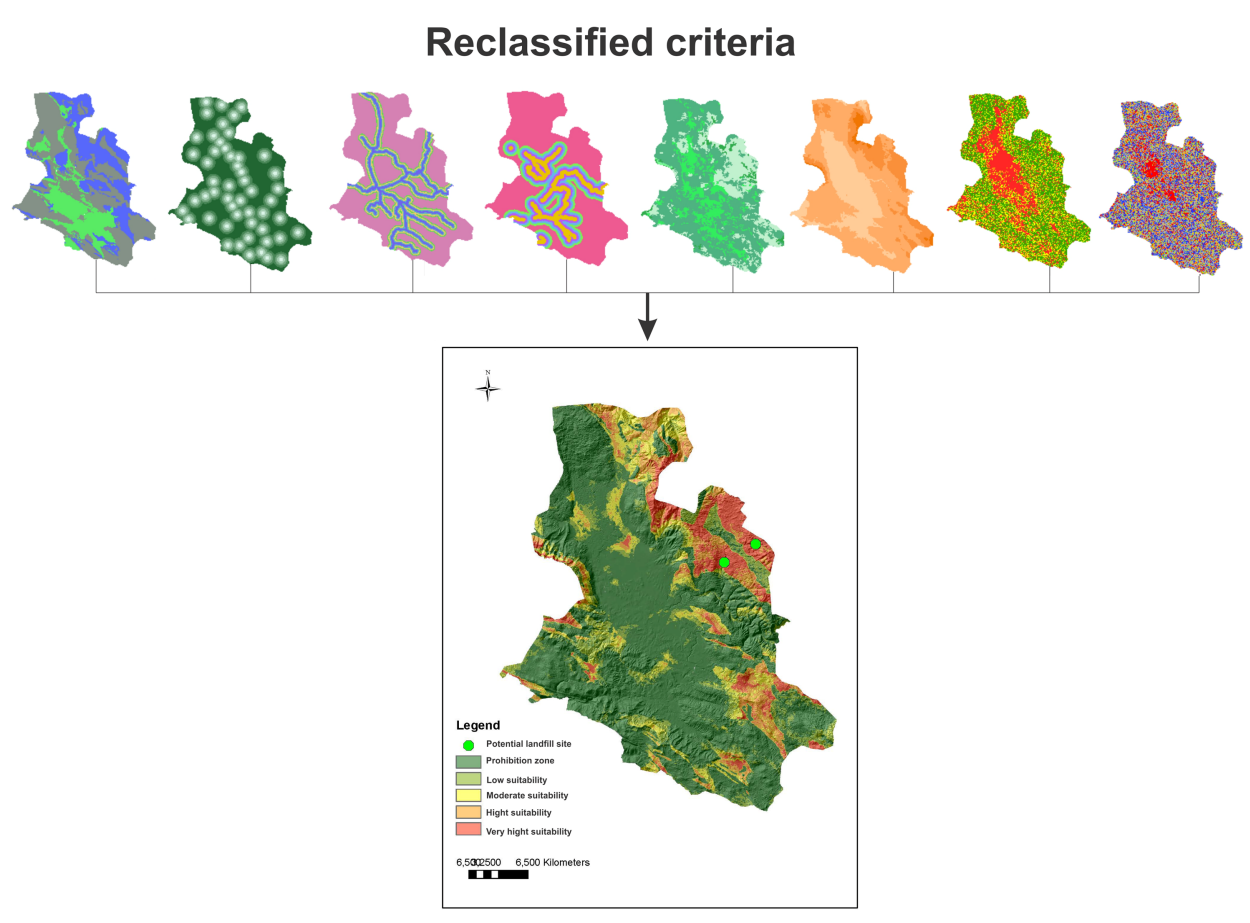

Figure 3 - Potential locations for landfills in the Municipality of Nevesinje Puc. 3 - Карта потенциальных участков для обустройства свалки, Муниципалитет Невесинье

Slika 3 - Karta potencijalnih lokacija deponija, opština Nevesinje

The analysis of the results shows that $67.0 \%$ of the territory belongs to the restricted zone, $11.0 \%$ of the territory has low suitability, $6.1 \%$ has moderate suitability, $5.9 \%$ has high suitability and $10.0 \%$ has very high suitability. Two potential sites suitable for the construction of a landfill are proposed. Both belong to the very high suitability zone. The visibility of a landfill from the settlements was also taken into account. The visibility was determined using the Viewshed tools.

However, before the final decision is made, it is necessary to visit the site as well as to analyze the ownership of the land, the land price and the opinion of the public and community structures.

\section{Conclusion}

Landfills are treated as objects of non-economic activities, while a landfill site selection is a special task in terms of the use of building plots and their price. 
In this paper, the selection of sites suitable for the construction of a landfill was carried out using GIS and the AHP. GIS was used for spatial statistics and grouping the most suitable areas, as well as for managing large amounts of spatial data collected from various resources. On the other hand, the AHP allows solving complex problems which depend on many factors. The paper defines two potential locations for the construction of a landfill in the Municipality of Nevesinje. The analysis was based on eight criteria: geology, distance from settlements, distance from road networks, distance from surface water bodies, vegetation, slope, altitude and aspect. Larger weights are assigned to environmental parameters (geology, distance from surface flows, etc.). The study identifies five suitable zones out of which $67.0 \%$ of the territory belongs to the restricted areas, $11.0 \%$ has low suitability, $6.1 \%$ has moderate suitability, $5.9 \%$ has high suitability and $10.0 \%$ has very high suitability.

The results can be used as a model for the landfill site selection in an area with similar characteristics, because it provides to the decisionmaker an analysis and support in solving problems related to waste management. Although a comprehensive analysis of the given factors for landfill site selection requires a lot of time and funds, the authors recommend its implementation. In this case, in order to comprehensively protect the environment and human health, it would be necessary to conduct the analysis of environmental risk assessment.

\section{Literature}

Akbari, V., 2008, Landfill Site Selection by Combining GIS and Fuzzy Multi Criteria Decision Analzsis, Case Study: Bandar Abbas, Iran, World Applied Sciences Journala 3, (Supple 1): pp.39-47.

Chang, N., Parvathinathan, G., \& Breeden, J.B., 2008., Combining GIS with fuzzy multicriteria decision-making for landfill siting in a fast-growing urban region, J. Environ. Manage, 87(1), pp.139-153. pmid:17363133.

ExpAhp 2.0, [Internet], Available on: <http://www.arcgis.com/home/item.html?id=bb3521d775c94b28b69a10cd184b7c1f>, Downloaded : Octobar,2015.

Gorsevski, P.V., Donevska, K.R., Mitrovski, C.D., \& Frizado, J.P., 2012, Integrating multi-criteria evaluation techniques with geographic information systems for landfill site selection: A case study using ordered weighted average. Waste Manag, 32(2), pp.287296. pmid:22030279.

Inđić, D., Luković, Z., \& Mučibabić, S., 2014, Model angažovanja jedinica ABH službe prilikom hemijskog udara. Vojnotehnički glasnik/Military Technical Courier, 62(1), pp.23-41.

Kontos, T.D., Komilis, D.P., \& Halvadakis, C.P., 2005, Siting MSW landfills with a spatial multiple criteria analysis methodology. Waste Manag, 25(8), pp.818-832. pmid:15946837.

Kontos, T., Komilis, D., \& Halvadakis, C.P., 2003, Siting MWS landfills on Lesvos island with a GIS based methodology, Wast Management, 21, pp.267-277.

Mahini, A.S., \& Gholamalifard, M., 2006, Siting MSW landfills with a weighted linear combination methodology in a GIS environment, International Journal of Environmental Science Technology, 160, pp.435-445. 
Melo, A.L.O., Calijuri, M.L., Duarte, I.C.D., Azevedo, R.F., \& Lorentz, J.F., 2006, Strategic decision analysis for selection of landfill sites, J Surv Eng, 132, pp.83-92.

Nas, B., Cay, T., Iscan, F., \& Berktay, A., 2010, Selection of MSW landfill site for Konya, Turkey using GIS and multi-criteria evaluation, Environmental Monitoring Assessment, 160, pp.491-500.

Nazari, A., Salarirad, M.M., \& Bazzazi, A.A., 2012, Landfill site selection by decision-making tools based on fuzzy multi-attribute decision-making method, Environ Earth Sci, 65, pp.1631-1642.

Official Gazette of the Republic of Srpska, 66/2003, Zakon o šumama Republike Srpske. JP „Službeni glasnik“.

Official Gazette of the Republic of Srpska, 75/2008, Zakon o šumama Republike Srpske, JP „Službeni glasnik“.

Official Gazette of the Republic of Srpska, 30/2010, Zakon o šumama Republike Srpske, JP „Službeni glasnik“.

Official Gazette of the Republic of Srpska, 28/1994, Zakon o upravljanju otpada Republike Srpske, JP „Službeni glasnik“.

Official Gazette of the Republic of Srpska, 50/2006, Zakonom o vodama Republike Srpske. JP „Službeni glasnik“.

Official Gazette of the Republic of Srpska, 92/2009, Zakonom o vodama Republike Srpske. JP „Službeni glasnik“.

Official Journal of the European Union, 2008, Directive 2008/98/EC of the European parliament and of the council of 19 November 2008 on waste and repealing certain Directives, pp.3-30, [Internet], Available on:

<http://eur-lex.europa.eu/LexUriServ/LexUriServ.do?uri=OJ:L:2008:312:0003:0030:en:PDF>, Downloaded : 15.10.2015.

Saaty, T.L., 2008, Decision making with the analytic hierarchy process. International Journal of Services Sciences, 1(1), pp.83-98. doi:10.1504/IJSSCI.2008.017590.

Saaty, T.L., 2000, Fundamentals of decision making and priority theory with the analytic hierarchy process, Pittsburgh, PA : RWS Publications.

Sener, B., Süzen, M., \& Doyuran, V., 2006, Landfill site selection by using geographic information systems, Environmental Geology, 49(3), pp.376-388. doi:10.1007/s00254-005-0075-2.

Sener, S., Sener, E., Nas, B., \& Karagüzel, R., 2010, Combining AHP with GIS for landfill site selection: A case study in the Lake Beyşehir catchment area (Konya, Turkey), Waste Manag, 30(11), pp.2037-46. pmid:20594819.

Siddiqui, M.Z., Everett, J.W., Vieux, B.E., 1996, Landfill Siting Using Geographic Information Systems: A Demonstration. Journal of Environmental Engineering, 122, pp.515-523.

Tayyebi, A.H., Dalevae, M.R., Tayyebi, A., \& Golobi, M., 2010, Combination multi criteria decision making and dempster shafer theorz for landfill site selection, International Archives of the Photogrammetry, Remote Sensing and Spatial Information Science, Vol. XXXVIII, Part 8, Kyoto Japan, pp.1073-1078.

Zamorano, M., Molero, E., Hurtado, A., Grindlay, A., \& Ramos, A., 2008, Evaluation of municipal landfill site in Southern Spain with GIS-aided methodology, Journal of Hazardous Materials, 160, pp.473-481.

Zelenović, T., Bajčetić, R., Srdljević, Z., \& Vojinović, Miloradov, M. 2011. GIS and The Analytic Hierarchy Process for Regional Landfill Site Selection in Transitional Countries: A Case Study From Serbia, Environmental Management.

http://www.esri.com/software/arcgis/arcgis-for-desktop.

http://www.opstinanevesinje.rs.ba/.

http://www.eea.europa.eu/data-and-maps/data/corine-land-cover-2006-raster-1. 


\title{
МЕТОДЫ ГИС ТЕХНОЛОГИИ АНАЛИТИЧЕСКОГО ИЕРАРХИЧЕСКОГО ПРОЦЕССА ПРИ ОПРЕДЕЛЕНИИ МЕСТОПОЛОЖЕНИЯ СВАЛОК
}

\author{
Драголюб Й. Секулович ${ }^{a}$, Гордана Л. Яковлевич ${ }^{б}$ \\ а Университет обороны г. Белград, Военная академия, г. Белград, \\ Республика Сербия, \\ ${ }^{\sigma}$ Университет в г. Баня-Лука и Архитектурно-строително-геодезичческий \\ институт, Баня-Лука, Республика Сербская, Босния и Герцеговина
}

ОБЛАСТЬ: геонауки

ВИД СТАТЬИ: оригинальная научная статья

ЯЗЫК СТАТЬИ: английский

Резюме:

Свалки наиболее распространенный вид размещения отходов. Выбор участка для размещения свалки представляет собой длительный и тщательный процесс, требующий выполнения целого ряда мероприятий при соблюдении законодательных актов, экологических, экономических и социальных нормативов и стандартов, с иелью снижения негативного воздействия на окружающую среду. В данной статье приведены испытанные местности на территории муниципалитета Невисинье (Республика Сербская) для обустройства свалок. Геомониторинг местности проводился методом аналитического иерархического прочесса (АНР) при помощи ГИС технологии. Анализ испытуемой местности включал следующие критерии: геологические изыскания, безопасное расстояние от населенных пунктов, безопасное расстояние от путей сообщения, безопасное расстояние от водоемов, вегетация, склоны и оползни, высота над уровнем моря и экспозиция на местности.

На основании примененного АНP метода определены относительные весовые коэффрициенты каждого из критериев, а их линейная соотнесенность с рангом каждой ячейки определяет весовой коэффрициент благоприятности. Весовой коэффрициент благоприятности распределен следующим образом: 67,0 \% запрещенная местность, 11,0\% несоответствующая местность, 6,1\% умеренная местность, 5,9\% благоприятная местность и 10\% наиболее благоприятная местность. На основании данных исследований было предложено два участка для обустройства свалки, но для окончательного согласования необходимо провести разведочные исследования и анализ дополнительных параметров.

Ключевые слова: свалка, местоположение, АНР, ГИС.

\section{ODREĐIVANJE LOKACIJE DEPONIJE PRIMENOM GIS}

TEHNOLOGIJE I ANALITIČKOG HIJERARHIJSKOG PROCESA

Dragoljub J. Sekulovića ${ }^{a}$ Gordana L. Jakovljevićb

a Univerzitet odbrane u Beogradu, Vojna akademija,

Beograd, Republika Srbija,

b Univerzitet u Banjoj Luci, Arhitektonsko-građevinsko-geodetski fakultet, Banja Luka, Republika Srpska, Bosna i Hercegovina. 
OBLAST: geonauke

VRSTA ČLANKA: originalni naučni članak

JEZIK ČLANKA: engleski

Sažetak:

Deponije su jedan od najčešćih načina odlaganja otpada. Izbor lokacije deponije je komplikovan i dug proces koji uključuje zakonske regulative, ekološke, ekonomske i socijalne parametre radi smanjenja negativnog uticaja na životnu sredinu. Izbor test-područja pogodne lokacije za deponiju na području opštine Nevesinje (Republika Srpska) izvršen je primenom analitičkog hijerarhijskog procesa (AHP) i GIS tehnologije. Analizirano je 8 kriterijuma: geologija, udaljenost od naselja, udaljenost od putne mreže, udaljenost od reka, vegetacija, nagiba terena, nadmorske visine i ekspozicija.

Primenom AHP definisani su relativni težinski faktori za svaki kriterijum, a njihovom linearnom kombinacijom s rangom svake ćelije određen je indeks pogodnosti. On je reklasifikovan u pet klasa pogodnosti, pri čemu 67,0\% prostora pripada području zabrane, $11,0 \%$ niske pogodnosti, 6,1\% umerene pogodnosti, 5,9\% visoke pogodnosti $i$ $10,0 \%$ području veoma visoke pogodnosti. Predložene su dve potencijalne lokacije za izgradnju deponije, ali pre donošenja konačne odluke potrebno je izvršiti obilazak lokacije $i$ analizirati dodatne parametre.

Ključne reči: deponija, izbor lokacije, AHP, GIS.

Paper received on / Дата получения работы / Datum prijema članka: 22. 11. 2015.

Manuscript corrections submitted on / Дата получения исправленной версии работы / Datum dostavljanja ispravki rukopisa: 22. 04. 2016.

Paper accepted for publishing on / Дата окончательного согласования работы / Datum konačnog prihvatanja članka za objavljivanje: 24. 04. 2016.

(C) 2016 The Authors. Published by Vojnotehnički glasnik / Military Technical Courier (www.vtg.mod.gov.rs, Втг.мо.упр.срб). This article is an open access article distributed under the terms and conditions of the Creative Commons Attribution license (http://creativecommons.org/licenses/by/3.0/rs/).

() 2016 Авторы. Опубликовано в "Военно-технический вестник / Vojnotehnički glasnik / Military Technical Courier" (www.vtg.mod.gov.rs, втг.мо.упр.срб). Данная статья в открытом доступе и распространяется в соответствии с лицензией "Creative Commons" (http://creativecommons.org/licenses/by/3.0/rs/).

(c) 2016 Autori. Objavio Vojnotehnički glasnik / Military Technical Courier (www.vtg.mod.gov.rs, втг.мо.упр.срб). Ovo je članak otvorenog pristupa i distribuira se u skladu sa Creative Commons licencom (http://creativecommons.org/licenses/by/3.0/rs/). 